\title{
Resource Use Efficiency in Cultivation of Major Food Crops under Rainfed and Irrigated Conditions in Northern Dry Zone of Karnataka
}

\author{
Rashmi K. S. ${ }^{1 *}$, Prakash Kammardi T. N. ${ }^{2}$, Afrin Zainb Bi. ${ }^{1}$ and Hamsa K. R. ${ }^{1}$
}

${ }^{1}$ Dept. of Agricultural Economics, UAS, GKVK, Bengaluru, Karnataka (560 065), India

${ }^{2}$ Karnataka Agriculture Price Commission, Sheshadri Road, Bengaluru, Karnataka (560 001), India

\section{Corresponding Author}

Rashmi K. S.

e-mail: ksrashmi4@gmail.com

\author{
Article History \\ Manuscript No. AR1759 \\ Received in $28^{\text {th }}$ December, 2016 \\ Received in revised form $18^{\text {th }}$ March, 2017 \\ Accepted in final form $6^{\text {th }}$ April, 2017
}

\begin{abstract}
The study is on resource use efficiency of the major rainfed and irrigated crops in Northern dry zone (NDZ) of Karnataka, India in $2013-14$. Bagalkot district was selected as a representative of Northern dry zone of Karnataka. The random sample of 90 farmers was chosen, 30 each belongs to cultivation under borewell irrigation, canal irrigation and rainfed condition, respectively. Cobb-Douglas production function was employed to assess the resource use efficiency in sugarcane under both borewell and canal irrigation and greengram under rainfed condition. DEA (Data envelope analysis) was used to find out the farm efficiencies of farmers in irrigated sugarcane, onion under borewell irrigation, sorghum and greengram were considered under rainfed condition for the analysis. The results indicated that MVP (Marginal value product) /MFC (Marginal factor cost) ratio for groundwater was less than one showed that there is no scope for further use of groundwater in the case of sugarcane under borewell irrigation. There is no scope for further use of human labour as ratio less than one in sugarcane under canal irrigation cultivation. While, in the case of rainfed greengram results depict that inefficient use of inputs such as fertilizers, human labour, seeds. DEA results represents that allocative efficiency of farmers in the study area were less than their technical efficiency. Therefore, this study concluded that there is a need to reallocate the resource in major crop cultivation in the study area and extension efforts has to initiate to guide farmers in order to increase their allocative efficiency with technical efficiency.
\end{abstract}

Keywords: DEA, technical efficiency, allocative efficiency, MVP

\section{Introduction}

India is one of the fastest growing economies in the world; it cracked the growth rate of 7.5\% in 2015 (IMF, 2016). The country is second most populated next to china in the world (StatisticsTimes, 2016). Despite of this, India has $22 \%$ of total population are living under the World poverty line of $\$ 1.25$ person $^{-1}$ day $^{-1}$ (Reserve Bank of India, 2014). Agriculture accounts $50 \%$ to the total workforce of the country (Central Intelligence Agency, 2017). In 2013-14, agriculture contributes $14 \%$ to the country's GDP (Central statistical organisation, 2015). Small and marginal farmers having land holding below 2 ha, they constitute $80 \%$ to the total farmers in the country. About $90 \%$ x of farmers depend on rain for the cultivation of crops (Centre for Education and Documentation, 2009). The per capita arable land was decreased from 0.34 to 0.12 during period 1961 to 2014 in the country (World Bank, 2016). In line with this efficient use of available resource to obtain optimum output to feed the rapid growing population of the country is essential. Thus, the study is main objective is to analyse resource use efficiency of the crops both under rainfed and irrigated condition in the study area.
The term resource use efficiency comprises technical efficiency, cost efficiency and allocative efficiency. Farmers have to allocate available inputs at optimal combination (least cost) for achieving the optimal output (maximum net returns) from their farm activities. This concept indicates that whether farmers are using resources efficiently or not to obtain the optimal output and also indicates the direction for resource use in future. The study of Kuber et al. (1965) indicated that farm earnings increases with increase in efficiency of labour and capital and input-output ratio. Farmers knowingly or unknowingly over exploited natural resources such as water, land and other resource for maximising their profit in short run. It may lead to the un-sustainability in farm production during long-run. Thus, it is important to analyse the resource use efficiency of the farmers, so that it directs future use of resources to get the optimal output. Geetarani and Charrabarty (2015) conducted a resource use efficiency study on rice in Manipur. The findings indicted that there was a large scope for adding fertilizer where the regression coefficients are positively and significantly related with rice yield but allocative efficiency score indicates fertilizer was under-utilized in rice production. Chapke et al. (2006) studied 
resource-use efficiency of sorghum production in rice fallows in Andhra Pradesh of India. The study showed that the regression coefficient of Cobb-douglas production function for sorghum crop has positive and significant were 0.54, 0.912 and 0.038 for expenditure on fertilizers, labourer and agrochemicals respectively. The results inferred that one per cent of expenditure on fertilizers, labourer and agrochemicals will leads to increase the $0.54,0.912$ and $0.038 \%$ of the returns respectively. The study of Bhende and Kalirajan (2007) in Karnataka indicated that there was inefficiency in the food and cash crops production. They suggested that there is a need to strengthen extension services and educate the farmers for improvement of farm efficiency. Singh et al. (2010) in their study indicated that about $40 \%$ water use efficiency on irrigated and rainfed lands would be necessary to compensate the additional water required for irrigation over next 25 years to meet additional food demand due to over population. Improved water use efficiency in agriculture will reduces the water requirement of the crops and also reduces the water losses which increased remarkable productivity of water used in the production of crops in the study water use efficiency to increase its productivity. Manjunath et al. (2011), conducted study to check the resource use efficiency of Bt cotton and non-Bt cotton in Hirekerur taluk of Haveri district (2011-12). The result found that gross returns would be reduce if increase in use of plant protection chemicals both in Bt and non- Bt cotton because of negative regression coefficient and MVP to $M F C$ ratio was negative in both $\mathrm{Bt}(-0.56)$ and non-Bt cotton $(-0.73)$. Thus, it suggested that to reduce the PPC in order to avoid decrease in yield. Kiresur and Manjunath (2011), used Cobb-Douglas production function to test the BT technology efficiency in cotton crop. The results revealed that technology found to be major contributor of total productivity difference between BT- cotton and non BT- cotton crop.

By reviewing the above literature noticed that resource use efficiency is an important criterion for farmers in order to maximise their net returns from farm. Previous studies indicated that resource use efficiency varies widely with agro-climatic zones. The literatures indicated that, there is a research gap in analysing resource use efficiency of Northern Dry Zone (NDZ) crops of Karnataka in India. Northern Dry Zone is the largest zone among the ten Agro-climatic zones of Karnataka. Bagalkot is the major district of Northern Dry zone. The cropping pattern of the district just apposed with that of Karnataka. In Bagalkot district about $40 \%$ of cropped area devoted to cereals and small millets and $13 \%$ to pulses and rest to commercial crops. In state of Karnataka $40 \%$ area occupied by the cereals and pulses, $13 \%$ to oilseed crops and rest to commercial crops. In the district $37 \%$ of area irrigated but area under rice farms meniscus $0.01 \%$ and the highest proportion of area shared by sugarcane crop, where this crop has highest consumptive use of water. Thus, the present study aimed to evaluate resource use efficiency and farm efficiency of major crops in Bagalkot district of Northern dry zone (NDZ), of Karnataka. Sugarcane is one of the major crops growing both under borewell and canal irrigation in the study area. Greegram is important crop under the rainfed condition in the selected sample.

\section{Materials and Methods}

The study is on resource use efficiency in cultivation of major crops under rainfed and irrigated conditions in Northern dry zone (NDZ) of Karnataka in India in 2013-14. Northern dry zone is the largest zone among ten agro-climatic zones of Karnataka, comprising 4.78 mha, spread over 35 taluks of the nine districts covering Viijayapura, Bagalkot, Bellary, Raichur, Dharwad, Koppal, Gadag, Haveri and Belagavi (Anonymous, 2013). This zone is characterised by scarce rainfall with erratic distribution, with an average rainfall of less than 600 $\mathrm{mm}$ (Anonymous, 2013). Thus, these districts were named as less rainfall districts. For this study Bagalkot district was selected as the sample district because the district area is dominated by agrarian nature and majority of the cropped area under rainfed, borewell and canal irrigation. Major crops grown in the district were jowar, maize, wheat, bajra, sugarcane, sunflower, pulses such as greengram, chickpea and oilseed crop groundnut. There is a diverse cropping pattern in the Bagalkot district with cereals, pulses, oilseed crops, commercial and other. The prominent commercial crops grown in the study area are sugarcane, cotton and onion. The district's average rainfall (1998-2010) is less than 600 $\mathrm{mm}$ despite of this it also ranks second in water intensive crop sugarcane area in Karnataka. In 2013, total irrigated area of Bagalkot district of Karnataka constitutes $55.31 \%$ of the net sown area of the district (Anonymous, 2013). Thus, the district was chosen as a representative district for Northern Dry Zone (NDZ). Random sampling technique employed in the selection of farmers for the study based purely on source of irrigation in Northern Dry Zone of Karnataka. A sample of 90 farmers considered further the sample was categorized into three groups with each of sample size 30 . The categories were rainfed farmers, borewell irrigated farmers and canal irrigated farmers.

\subsection{Analytical tools used}

Resource use efficiency in sugarcane both under borewell and canal irrigated cultivation and green gram under rainfed condition was studied by fitting the Cobb-douglas type production functions to the farm level data.

The specification of the equation was as follows, $\mathrm{Y}=\mathrm{a} \mathrm{X}_{1}^{\mathrm{bl}} \mathrm{X}_{2}^{\mathrm{b} 2} \mathrm{X}_{3}^{\mathrm{b} 3} \mathrm{X}_{4}^{\mathrm{b} 4} \mathrm{X}_{5}^{\mathrm{b} 5}$ Where,

$\mathrm{Y}=\mathrm{Gross}$ Returns of each crop per farm (₹)

$\mathrm{X}_{1}=$ Expenditure on Fertilizer per farm for each crop (₹)

$X_{2}=$ Expenditure on water per farm for each crop (₹)

$X_{3}=$ Other variable cost per farm per each crop ( $₹$ )

$\mathrm{X}_{4}=$ Human labour per farm for each crop in man days $\mathrm{X}_{5}=$ Seed quantity per farm for green gram in kilograms $a=$ intercept, $b_{1}, b_{2}, b_{3}, b_{4}$ and $b_{5}=$ elasticity of production The equation (1) was converted into the logarithmic form; it is assumed a log linear equation as specified below: $\operatorname{Ln} Y=a+b_{1}\left(\operatorname{LnX} X_{1}\right)+b_{2}\left(\operatorname{Ln} X_{2}\right)+b_{3}\left(\operatorname{LnX}_{3}\right)+b_{4}\left(\operatorname{Ln} X_{4}\right)+b_{5}\left(\operatorname{Ln} X_{5}\right)$ Three Cobb-Douglas equations were fitted for sugarcane both under borewell and canal irrigation and greengram under 
rainfed cultivation. Where, $\mathrm{X}_{1}, \mathrm{X}_{2}, \mathrm{X}_{3}$ and $\mathrm{X}_{4}$ were considered for assessing the resource use efficiency of sugarcane under borewell and canal irrigation. While in the case of rainfed greengram in addition to $X_{1}, X_{3}, X_{4}$ and $X_{5}$ were because of rainfed cultivation there was no expenditure on water and seed is the main input in the crop cultivation.

\subsection{Marginal value product (MVP)}

By studying the marginal value productivity of factors of production, we can assess their relative importance. Marginal Value Productivity of $X_{i}$, where $i$ is a input is estimated by the following formula:

$M V P=\frac{b_{i} \times G \cdot M \cdot(Y)}{G \cdot M\left(X_{i}\right)}$

G.M. $(Y)$ and G.M. $\left(X_{i}\right)$ represent the geometric means of output and input respectively and $b_{i}$ is the regression coefficient of $\mathrm{i}^{\text {th }}$ input.

Based on economic theory, a firm maximizes profits with regard to resource use when the ratio of the marginal return to the opportunity cost is one. The values are interpreted thus, If $r<1$; resource is excessively used or over utilized hence decreasing the quantity use of resource increases profits.

If $r>1$; resource is under used or being underutilized hence increasing its rate of use will increase profit level.

If $r=1$; it shows the resource is efficiently used, that is optimum utilization of resource hence the point of profit maximization.

\subsection{Technical, allocative and cost efficiencies}

Technical efficiency (TE) refers to the ability of a farmer to produce the maximum feasible output from a given bundle of inputs, or the minimum feasible amounts of inputs to produce a given level of output. Allocative efficiency ( $A E)$ refers to the ability of a technically efficient farmer to use inputs in proportions that minimize production costs given input prices. Allocative efficiency is calculated as the ratio of the minimum costs required by the farm to produce a given level of outputs and the actual costs of the farm adjusted for TE. Economic efficiency (EE) is the product of both TE and AE. Thus, a farmer is economically efficient if it is both technically and allocatively efficient.

\subsection{Data envelopment analysis (DEA)}

The DEA method is a frontier method that does not require specification of a functional form or a distributional form, and can accommodate scale issues. DEA was applied by using both classic models CRS (constant returns to scale) and VRS (variable returns to scale) with input orientation, in which one seeks input minimization to obtain a particular product level. Under assumption of constant returns to scale, linear programming model used to measure the farm efficiencies (Coelli et al., 1998).

\section{Results and Discussion}

In order to obtain the resource use efficiency of inputs used in crop production, functional analysis was performed for sugarcane under both borewell and canal irrigated condition.
While, green gram considered for the analysis under rainfed situation.

For sugarcane production under borewell irrigation, the Cobb Douglas production function was estimated. The estimated model was found significant as calculated $F$ value was greater than the critical $F$ value, besides the model explains about $92 \%$ variation in the borewell irrigation in terms of sugarcane production. The results showed that, the positive influence of fertilizer and groundwater use on sugarcane production in borewell condition. In order to study the resource use efficiency, the ratio of marginal value product (MVP) of each input to marginal factor cost (MFC) of each input was computed (Table 1). The results indicated that expenditure on fertilizer had resource use efficiency above unity, implying the scope for aiming at the optimal output by use of fertilizer. In the case of groundwater, the MVP/MFC ratio was 0.95, indicating that the present level of groundwater use is suboptimal (over utilised) and there is no scope for further increase of the groundwater use.

The Cobb Douglass production function was estimated

Table 1: Resource use efficiency in sugarcane (borewell irrigation)

\begin{tabular}{lcccc}
\hline Variables & EP & MVP & MFC & $\begin{array}{c}\text { MVP/MFC } \\
\text { ratio }\end{array}$ \\
\hline Fertilizer (₹) & $0.18^{*}$ & 1.78 & 1.00 & 1.78 \\
Water cost (₹) & $0.30^{* *}$ & 0.95 & 1.00 & 0.95 \\
Other variable cost (₹) & 0.18 & 1.80 & 1.00 & 1.80 \\
Human labour (Man & -0.05 & -81 & 200 & $\mathrm{NR}$ \\
days) & & & & \\
F Value & & & & 76.74 \\
$\mathrm{R}^{2}$ & & & & 0.92 \\
\hline
\end{tabular}

EP: Elasticity of production; MVP: Marginal value product

(₹); MFC: Marginal factor cost (₹) ; 'Significant at $(p=0.05)$;

${ }^{* *}$ Significant at $(p=0.01)$, NR: Not relevant

for evaluating the resource use efficiency in the canal irrigated sugarcane cultivation (Table 2). Model adequacy was examined with the help of the coefficient of multiple

Table 2: Resource use efficiency in sugarcane (canal irrigation)

\begin{tabular}{lcccc}
\hline Variables & EP & MVP & MFC & MVP/MFC \\
\hline Seed (₹) & 0.03 & 50.80 & 105 & 0.50 \\
Fertilizer (kg.) & $0.18^{*}$ & 298.72 & 17 & 1.75 \\
$\begin{array}{l}\text { Human labour (Man } \\
\text { days) }\end{array}$ & $0.82^{*}$ & 202.83 & 200 & 1.01 \\
Capital cost (₹) & 0.01 & 0.27 & 1 & 0.27 \\
F Value & & & & 29.55 \\
R $^{2}$ & & & & 0.87 \\
\hline
\end{tabular}

${ }^{*}$ Significant at $(p=0.05)$ 
determination ( $R^{2} 0.87$ ) and the $F$ value was 29.55 . Thus the model was significant and explained $87 \%$ variation from the variable included in the model indicating cultivation of sugarcane under canal irrigation. The results showed the positive influence of fertilizer quantity and human labour use on sugarcane production under canal condition. In order to study the resource use efficiency, the ratio of MVP of each input to MFC computed and compared to the MFC of that input was computed (Table 2). The results indicated that quantity of fertilizer had resource use efficiency above unity, implying that the scope for aiming at the optimal output. Whereas, ratio of MVP to MFC for human labour employed in sugarcane cultivation under canal irrigation approximates to unity, therefore human labour was optimally used. The usage of fertilizer needs to be increased in the canal irrigated areas.

Similarly, Cobb Douglass production function was used to evaluate the resource use efficiency of green gram crop under rainfed cultivation (Table 3). Model adequacy was examined with the help of the coefficient of multiple determination $\left(R^{2} 0.73\right)$ and the $F$ value was 14.01 . The

\begin{tabular}{lcccc}
\hline \multicolumn{5}{l}{ Table 3: Resource use efficiency in greengram (rainfed) } \\
\hline Variables & EP & MVP & MFC & MVP/MFC \\
\hline Seed (kg)) & $0.3^{* *}$ & 428 & 54 & 7.92 \\
Human labour (Man & $0.64^{*}$ & 325 & 200 & 1.62 \\
days) & & & & \\
Fertilizer (kg.) & 0.15 & 29 & 17 & 1.73 \\
Capital cost (₹) & -0.07 & - & 1.00 & NR \\
F Value & & & & 14.01 \\
$R^{2}$ & & & & 0.73 \\
\hline
\end{tabular}

*Significant at $(p=0.05) ;{ }^{* *}$ Significant at $(p=0.01)$

estimated regression model was significant with coefficient of multiple determination $\left(R^{2}\right)$ was 0.73 and explains about $73 \%$ of the variation of the gross returns in the case of green gram under rainfed situation. The results of resource use efficiency in green gram showed that, the MVP to MFC ratio for human labour was 1.62, while it was 7.92 for seed and 1.75 for fertilizer. This indicates that human labour, quantity of fertilizer and quantity of seed used were not utilized optimally; therefore there is a need to reallocate these inputs to achieve optimum gross returns.

3.1. Technical, allocative and economic efficiency rainfed farmers

Technical, allocative, cost efficiency of farmers in sorghum and green gram production under rainfed condition were computed and presented in Table 4. The results showed that 33 and $44 \%$ of farmers producing sorghum and green gram under rainfed situation have technical efficiency score of range between 0.91 and 1, respectively. The results implied that these farmers were technically efficient. Whereas, the cost efficiencies were 40 and $52 \%$ in sorghum and green gram growing farmers, respectively, represents the score less than
Table 4: Technical, allocative and economic efficiency of rainfed farmers in Northern dry zone, 2013-14

\begin{tabular}{lcccccccc}
\hline \multirow{2}{*}{ Crops } & & \multicolumn{3}{c}{ Sorghum } & & \multicolumn{3}{c}{ Green gram } \\
\cline { 1 - 3 } \cline { 7 - 9 } Efficiencies & & TE & AE & CE & & TE & AE & CE \\
\hline$<0.5$ & $0(0)$ & $1(7)$ & $3(20)$ & $3(12)$ & $1(4)$ & $6(24)$ \\
0.5 to 0.6 & $2(13)$ & $1(7)$ & $3(20)$ & $2(8)$ & $1(4)$ & $7(28)$ \\
0.61 to 0.7 & $4(27)$ & $2(13)$ & $4(27)$ & $4(16)$ & $7(28)$ & $4(16)$ \\
0.71 to0.8 & $2(13)$ & $4(27)$ & $2(13)$ & $2(8)$ & $5(20)$ & $3(12)$ \\
0.81 to0.9 & $0(0)$ & $3(20)$ & $2(13)$ & $3(12)$ & $8(32)$ & $4(16)$ \\
$>0.91$ to 1 & $5(33)$ & $4(27)$ & $1(7)$ & $11(44)$ & $3(12)$ & $1(4)$ \\
Total & 15 & 15 & 15 & & 25 & 25 & 25 \\
Mean & 0.81 & 0.76 & 0.62 & 0.81 & 0.76 & 0.61 \\
\hline
\end{tabular}

Figures in the parentheses indicates to percentage to total number; TE: Technical efficiency; AE: Allocative efficiency; CE: Cost efficiency; Variables considered: Gross returns (₹), Human labour (Man days), Machine labour (hours), Seed (kg), Fertilizer (kg), Farm Yard manure (FYM) (Tractor load)

0.6. Overall in rainfed crops, sorghum and green gram in Northern dry zone of Karnataka, it was found that the mean technical efficiency, allocative efficiency and cost efficiency score for sorghum were $0.81,0.76$ and 0.62 , respectively, whereas in case of green gram the mean technical efficiency, allocative efficiency and cost efficiency score were $0.81,0.76$ and 0.61 , respectively. The mean scores of technical efficiency, allocative efficiency and cost efficiency score of sorghum and green gram were comparable among the rainfed farmers.

3.2. Technical, allocative and economic efficiency of irrigated farmers

The major irrigated crops in Northern dry zone were sugarcane both under canal and borewell irrigation and onion under borewell irrigation. Therefore, the technical, allocative and cost efficiency of irrigated farmers for different crops were analysed using data envelope analysis (Table 5). There were about more than $60 \%$ of farmers scored technical efficiency between 0.9 and 1 in case of sugarcane under both borewell and canal irrigation. Whereas, in case of onion with borewell irrigation $60 \%$ farmers were scored the technical efficiency score of ranging between 0.9 and 1 , and these farmers were technically efficient. Whereas the cost efficiency of $65 \%$ and $34 \%$ of farmers cultivating sugarcane under canal and borewell irrigated conditions, respectively and eighty per cent of farmers growing onion under borewell were scored less than 0.5 .

The mean score of efficiencies was highest in technical efficiency followed by cost efficiency and allocative efficiency. The difference between technical and cost efficiency score for irrigated farmers was 0.3 , which was 0.1 in the case of rainfed farmers indicating that irrigated farmers were less efficient compare to the rainfed farmers. Because irrigated farmers have less constraints such as credit, access to inputs 


\begin{tabular}{|c|c|c|c|c|c|c|c|c|c|}
\hline \multirow{2}{*}{$\begin{array}{l}\text { Crop } \\
\text { Efficiencies }\end{array}$} & \multicolumn{3}{|c|}{ Sugarcane canal } & \multicolumn{3}{|c|}{ Sugarcane borewell } & \multicolumn{3}{|c|}{ Onion borewell } \\
\hline & $\mathrm{TE}$ & $\mathrm{AE}$ & CE & TE & $\mathrm{AE}$ & CE & TE & $\mathrm{AE}$ & CE \\
\hline$<0.5$ & $0(0)$ & $13(65)$ & $13(65)$ & $0(0)$ & $7(24)$ & $10(34)$ & $0(0)$ & $16(80)$ & $16(80)$ \\
\hline 0.5 to 0.6 & $2(10)$ & $2(10)$ & $2(10)$ & $0(0)$ & $4(14)$ & $8(28)$ & $2(10)$ & $3(15)$ & $3(15)$ \\
\hline 0.61 to 0.7 & $1(5)$ & $0(0)$ & $0(0)$ & $0(0)$ & $4(14)$ & $3(10)$ & $3(15)$ & $0(0)$ & $0(0)$ \\
\hline 0.71 to 0.8 & $5(25)$ & $1(5)$ & $1(5)$ & $1(3)$ & $8(28)$ & $4(14)$ & $0(0)$ & $0(0)$ & $0(0)$ \\
\hline 0.81 to 0.9 & $2(10)$ & $2(10)$ & $3(15)$ & $10(34)$ & $3(10)$ & $3(10)$ & $3(15)$ & $0(0)$ & $0(0)$ \\
\hline$>0.91$ to 1 & $12(60)$ & $4(20)$ & $3(15)$ & $18(62)$ & $3(10)$ & $2(7)$ & $12(60)$ & $1(5)$ & $1(5)$ \\
\hline Total & 22 & 22 & 22 & 29 & 29 & 29 & 20 & 20 & 20 \\
\hline Mean & 0.91 & 0.51 & 0.49 & 0.94 & 0.66 & 0.62 & 0.87 & 0.38 & 0.34 \\
\hline
\end{tabular}

Note: Figures in the parentheses indicates percentage to total number; TE: Technical efficiency; AE: Allocative efficiency; CE: Cost efficiency; Variables considered: Gross returns (₹), Human labour (Man days), Machine labour (hours), Seed (kg.), Fertilizer (kg.), FYM (Tractor load), Water (acre inches)

(fertilizers, seeds, and human labour), transaction costs than the rainfed farmers. In the case of irrigated farmers, water cost considered as one input with other inputs. In the previous section the results indicated the usage of groundwater level is sub optimal. Thus, irrigated farmers were less efficient compare to rainfed farmers.

\section{Conclusion}

Resources were not optimally utilized in most of the crops (MVP/MFC $<1)$, therefore there is a need to reallocate the resources. Technical efficiency component needs to be further strengthened by educating / training to farmers with regard to allocative efficiency in most of the crops. Especially it required in the case of labour and irrigation water inputs. The WALMI (Water and land management institute) and other water organizations, Agricultural and Horticulture Department need to play a prominent role in this regard.

\section{References}

Anonymous, 2013. Area and population and census data. available from: http://www.bagalkot.nic.in/index-en. html.

Bhende, M.J., Kalirajan, K.P., 2007. Technical efficiency of major food and cash crops in Karnataka (India). Indian Journal of Agriculture Economics 62(2), 176-191.

Central Intelligence Agency, C., 2017, January 12. The world fact book. Available from: https://www.cia.gov/library/ publications/the-world-factbook/geos/in.html.

Central Statistical Organisation, C., 2015. Share of agriculture and livestock sector in GDP. Available from http://www. nddb.org: http://www.nddb.org/information/stats/ GDPcontrib.

Centre for Education and Documentation, C., 2009, July. Agriculture, food and small farmer in India. Available from http://base.d-p-h.info: http://base.d-p-h.info/en/ fiches/dph/fiche-dph-8104.html.
Chapke, R.R., Mondal, B., Mishra, J.S., 2006. Resource use efficiency of sorghum (Sorghum bicolor) production in rice (Oryza sativa)-fallows in Andhra Pradesh. Journal of Human Ecology 34(2), 87-90.

Tim, C., 1998. A guide to DEAP version 2.1, a data envelopment analysis (Computer) Program. Available from: http:// www.owlnet.rice.edu/ econ380/DEAP.PDF.

Geetarani, D.L., Chakrrabarty, S.Y., 2015. Resource use and technical efficiency of rice production in Manipur. International Journal of Development Research 5(05), 4403-4411.

IMF, 2014. Gross domestic product based on purchasingpower-parity (PPP) valuation of country GDP. Available from: https://www.imf.org/external/pubs/f (Geetarani \& Dr. Chakrrabarty, 2015)t/weo/data/changes.htm.

Kiresur, V.R., Ichangi, M., 2011. Socio-economic impact of Bt cotton-a case study of Karnataka. Agricultural Economics Research Review 24, 67-81.

Kuber, R., Chowdhari, T.P.S., 1965. Resource use efficiency in agriculture-A critical survey of the literature. Indian Journal of Agricultural Economics 20(4), 1-14.

Manjunath, K., Dhananjaya Swamy, P.S., Jamkhandi, B.R., Nadoni, N.N., 2011. Resource use efficiency of Bt cotton and non-Bt cotton in Haveri district of Karnataka. International Journal of Agriculture and Food Science Technology 4(3), 253-258.

Singh, R., Kundu, D.K., Bandyopadhyay, K.K., 2010. Enhancing agricultural productivity through enhanced water use efficiency. Journal of Agricultural Physics 10(2), 1-15.

Statistics Times, 2016. Population of India. Available from http://statisticstimes.com/: http://statisticstimes.com/ population/population-of-india.php.

World Bank, W., 2016. Arable land (hectares per person). Available from http://data.worldbank.org: http://data. worldbank.org/indicator/AG.LND.ARBL.HA.PC. 